Paideusis

\title{
Teaching Philosophy of Education: The "Discussion - Case Study Approach"
}

\section{John Portelli}

Volume 4, Number 1, 1990

URI: https://id.erudit.org/iderudit/1073392ar

DOI: https://doi.org/10.7202/1073392ar

See table of contents

Publisher(s)

Canadian Philosophy of Education Society

ISSN

0838-4517 (print)

1916-0348 (digital)

Explore this journal

Cite this article

Portelli, J. (1990). Teaching Philosophy of Education: The "Discussion - Case

Study Approach". Paideusis, 4(1), 25-31. https://doi.org/10.7202/1073392ar viewed online.

https://apropos.erudit.org/en/users/policy-on-use/ 


\section{Teaching Philosophy of Education: The "Discussion - Case Study Approach"}

\section{John Portelli}

\section{Mount Saint Vincent University}

The aim of this paper is to argue for the "discussion - case-study approach" in the teaching of introductory courses in philosophy of education at the pre-service level. The paper offers a rationale for the use of this approach by identifying and briefly criticizing some of the popular but negative views about the nature and role of philosophy of education in teacher education. The second part will very briefly describe the approach, comment on the students' reaction to it, and make some suggestions. ${ }^{1}$

\section{Part I}

Why are foundations courses, including philosophy of education, viewed as being incompatible with the other pre-service courses and not helpful to education students? The popular perception is that philosophical questions and concerns are trivial and irrelevant because they are too theoretical and, therefore, can be safely ignored by the practitioner. Some argue that, since philosophers have offered different and opposing views, teachers do not have anything to gain from philosophy of education. Similar views are also held with regard to theory and research in general. As Carr and Kemmis put it, "teachers regard research as an esoteric activity having little to do with their everyday practical concerns." 2 This is not surprising if one holds that teacher education programmes are highly dominated by "technicism?" which is characterized by a "how to" or "quick-fix approach," as well as elements of anti-intellectualism, extreme pragmatism, and vocationalism. ${ }^{3}$ This perspective is also reflected in the work and attitude of teachers who, as Ohanian maintains, "demand. . .carryout formulae, materials with the immediate application of scratch-and-sniff stickers. . .as though each of us were heading to operate a fast-food franchise." 4 Ohanian believes that such a perspective arises from (i) a mistaken belief that there are "instant, stir-and-serve recipes for running a classroom" and (ii) a over-emphasis of administration on test scores. This technicism, according to Giroux and McLaren, is based on "the logic of instructional technology and mandated by the state to provide requisite technical and managerial expertise." 5 And this perspective has led to the deskilling and disempowering of teachers, discouragement of a critical view of schooling and an acceptance and reproduction of current practice. ${ }^{6}$

Given such attitudes, it is not surprising that "the dominant approach to the preparation of teachers emphasizes a combination of courses in educational psychology and in the methodology of the various content areas."7 The influence of technicism and the popularity of extreme pragmatism and vocationalism in teacher education lead almost naturally "to an isolation of the educational encounter so that the sort of educational issues that are crucial in the foundations of education tend to be regarded as irrelevant or even counterproductive." 8 Not only are these educational issues disregarded, but through the use of the dominant technicist approach, students learn that "being a teacher. . means identifying knowledge that is certain, breaking it into manage- 
able bits, and transmitting it to students in an efficient fashion. Being a student means acquiring this knowledge and learning how to use it in a context which does not include criticism and has little patience with analysis." 9 Within this approach, anything that deviates from the above norm is deemed useless and unimportant. But the foundations, if done well, of their very nature ought to challenge this approach as well as the practices that go with it. This dichotomy or conflict between the foundations perspective and technicist practices is also recognized by some teachers. ${ }^{10}$

The separation between foundations and other courses arises both because of the dominant practices found in teacher education described above, and the widespread attitude towards the foundations and research held by teachers. But I also believe that "foundations instructors must bear some of the responsibility for the distance which exists between these areas and the discontent which results." 11 This latter point leads to issues concerning the nature and role of philosophy of education, the relationship between theory and practice, and the way philosophy of education courses are conducted.

One can identify at least two approaches adopted in the teaching of philosophy of education. The first deals with the traditional 'isms' in philosophical discourse - such as realism, idealism, and progressivism - and then attempt to identify what educational prescriptions follow from these "philosophies." Within this approach - which is usually associated with traditional or pre-analytic philosophy of education, some argue that philosophy of education and educational theory become almost identical. The second approach, which arose as a reaction to the first, is associated with analytic philosophy of education. This approach to philosophy of education deals with the analysis of central educational concepts. Philosophy is viewed as "concerned with questions about the analysis of concepts and with questions about the grounds of knowledge, belief, actions, and activities." 12

Whichever approach one adopts, one still needs to address the question of what teaching method is to be used in philosophy of education classes. In a recent article which comments on the methods of teaching philosophy of education, Johnston and Applefield write:

The approach typically used to teach educational philosophy is based upon utilization of philosophical concepts and principles to allow students to engage in a process of analysis of historical and contemporary educational practices. Classroom activity is typically characterized by students reading assigned material and attending lectures which describe identified philosophical positions. They then discuss this material and finally analyze the philosophic underpinnings of a text, policy, or personal belief. At a more existential level, this approach may be described as one in which faculty lecture to students and grumble among themselves about lack of student engagement with questions. Students commonly memorize material for an objective exam and, in a final flourish to attain relevance, generate a written statement of their philosophy of education to underpin the teaching practices they would adopt. ${ }^{3}$

Given the concern that philosophy of education courses do not relate to other courses in education, do not illuminate practice, do not resolve anything, are not helpful for the students' chosen profession and that students do not have enough experience or practice to make sense of them, I have attempted to use and 
evaluate the "discussion - case-study approach" with two groups of B.Ed. students totalling fifty-three students.

The rationale for using this approach rests on at least three points:

(1) My view about the nature and role of philosophy of education

Philosophy of education is viewed as the critical inquiry of educational concepts, values, and practices. Philosophy is seen as "an activity; it is something you do rather than a body of subject matter you study,"14 and, therefore, as Gramsci concludes, "philosophy is not ... the intrusion into everyday life of an alien esoteric otiose knowledge but an essential dimension of essential human experience. . it is the criticism and superarching of common sense." 15

(2) The importance of doing philosophy if one values a critical-reflectiveinquiring approach to teaching.

Several complaints have been raised about the "traditional pedagogical practices of preservice education" - practices followed by professors who at the same time preach the value of inquiry instruction. Unfortunately, as Ross and Hannay note: "Students often encounter the reflective inquiry model as content to be memorized for an upcoming examination rather than as a process used to solve real problems." 16

(3) My belief that philosophy of education has something to offer to the resolution of practical, educational issues.

\section{Part II}

The approach adopted is heavily based on a combination of large-group and small-group discussions of case-studies as well as readings related to issues raised in them. ${ }^{7}$ A case study consists of "an account of an event or events in the life of teachers and schools." 18 It is not an example to support or explain a point or "a morality tale or fable." The reasons for using case studies are: (i) to provide students with a context which raises a controversial issue or issues; (ii) to give students the opportunity to explore the different aspects of the issue or issues by analyzing, discussing, and providing arguments for a position they might hold in resolving the issue; (iii) to help students relate the readings to practical concerns and develop practical judgement; and (iv) to help students clarify their own views and reasons for them.

The students' course evaluation ratings and written comments with regard to (a) their improvement of their ability to think critically, (b) the value of the philosophical readings, (c) the value of philosophy of education in relation to their professional goals, (d) the value of philosophy of education in clarifying and resolving practical educational issues, (e) the value of philosophical discussions. They show that the use of the "discussion - case-study approach," while being faithful to the nature of philosophical inquiry, has helped in correcting some of the popular misgivings about philosophy of education. ${ }^{19}$ The students' evaluations and comments discredit the popular, but negative, views about the foundations. ${ }^{20}$

The approach defended in this paper assumes a certain nature and role of philosophy of education, as well as a certain perspective to the theory/practice relationship. Both of these assumptions contrast with the "technicism" prevalent in teacher education programmes. As I said earlier, this dominant 
view aims for a one-to-one correspondence between theory and practice. Theoreticians, who do the thinking, are expected to offer prescriptions that work; teachers, who follow the directions, as practitioners, are expected to implement these prescriptions. Within this perspective, theory is meant to offer quick solutions that apply to all cases or contexts, and the simpler, more concrete or direct the suggestions the better, because teachers will carry them out more efficiently. As Pinar and Grumet observe, theory "has become a mere appendage. . .judged and justified solely according to its ability to predict and control those [human] affairs." 21 Such an atmosphere erases "the boundary between the actual and the possible by acknowledging the possible only in its existing and predictable manifestations in the practical world." 22

From the critical-foundational perspective, the "technicist" understanding of the role of theory is deemed to be too reductionist and problematic. As Entwistle argues, there can never be a one-to-one correspondence between theory and practice, that is, one that "predicts accurately every contingency in a practical situation." 23 The role of theory is "to evoke judgement rather than rote obedience," to bring "critical intelligence to bear on practical tasks rather than merely implementing good advice."24 Or, as Pinar and Grumet put it, the role of theory is "to consciously question [the practical], interrupting the predictable with analyses that point to other possibilities" and "to restore the contemplative moment in which we interrupt our taken-for-granted understandings. . . and ask again the basic questions practical activity silences." 25 The students' comments with regard to the use of case studies and discussions ${ }^{26}$ and the way the issues dealt with in this course relate to other courses ${ }^{27}$ indicate that the students are aware of the role of theory defended in this paper and throughout the course. I am not claiming that this is simply the result of this course. However, the majority of the students' comments show that the issues dealt with in the course as well as the approach adopted have helped them to become aware of the need to consider these issues within their teaching, to realize the importance of thinking for themselves, to appreciate criticism, and value "patience with analysis." 28

As a result of the use and analysis of the evaluation of the "discussion case-study approach," I propose the following suggestions. First, that while we should continue to improve the teaching of philosophy of education courses, we also need to combat and eliminate "technicism" in teacher education. If the latter fails, then philosophy of education courses are doomed to be seen as being incompatible with the other courses offered in teacher education. The philosophical perspective will remain perhaps the necessary or required perspective but the odd and disliked one.

My second suggestion, which is not unrelated to the first, is to introduce the philosophical perspective, even if partially, in other courses offered in teacher education programmes. This, of course, implies, at least in some instances (I imagine in most instances), that philosophers of education have to take curriculum matters more seriously and even be willing to co-teach some of the other courses. 


\section{Notes}

1This is a short version of a paper presented at the Learned Societies' meetings at Laval University, June 1989. Given the suggested length for publication, I will be unable to give all the details about the approach and the survey carried out with the students. More details are available upon request.

${ }^{2}$ W. Carr and S. Kemmis, Becoming Critical (London: Falmer Press, 1986), 8.

${ }^{3}$ See, M. Apple and K. Teitlebaum, "Are Teachers Losing Control of their Jobs," Social Education, 49(5), 1985, 372-375; S. Adler and J. Goodman, "Critical Theory as a Foundation for Methods Courses," Journal of Teacher Education, 37(4), 1986, 2-8; L.E. Beyer, "Beyond Elitism and Technicism: Teacher Education as Practical Philosophy," Journal of Teacher Education, 37(2), 1986, 37-41; T.S. Popkewitz, Critical Studies in Teacher Education (London: Falmer Press, 1987); L. Beyer, "Training and Education: A Critique of Technical-Mindedness in Teacher Preparation," Current Issues in Education, vii, (Fall)1988, 21-40; L. Beyer, Knowing and Acting: Inquiry, Ideology and Educational Studies (London: Falmer Press, 1988); H. Giroux and P. McLaren, "Teacher Education and the Politics of Democratic Reform," in H. Giroux, Teachers as Intellectuals (Hadley, Mass.: Bergin and Garvey, 1988), 158-176; L. Beyer, "Reconceptualizing Teacher Preparation: Institutions and Ideologies," Journal of Teacher Education, 40(1), 1989, 22-26.

${ }^{4}$ S. Ohanian, "On Stir-and-Serve Recipes for Teaching," in K. Ryan and J.M. Cooper (eds.), Kaleidoscope (Boston: Houghton Mifflin Co., 5th ed.), 56.

${ }^{5}$ Giroux and McLaren (1988), op. cit., 161.

${ }^{6}$ See, M. Apple and L. Weis (eds.), Ideology and Practice in Schooling (Philadelphia: Temple University Press, 1983); Giroux and McLaren (1988), op. cit.; Beyer (1988), op. cit.

${ }^{7}$ Beyer (1989), op. cit., 22.

${ }^{8}$ Ibid.

${ }^{9}$ L.E. Beyer and K.M. Zeichner, "Teacher Training and Educational Foundations: A Plea for Discontent," Journal of Teacher Education, 33(3), 1982, 20.

${ }^{10}$ Consider, for example, the following journal entry by a graduate student and an elementary school teacher with fifteen years of teaching experience: "In the public schools that I have been in, teachers who criticize or try to change the system - those who don't believe in what they are told to teach or do - are not valued. They are disciplined by principals and administrative personnel. School board officials value those teachers who act only as technicians, who believe in the status quo, and who do not question even their own beliefs. Teachers are made to believe that their own feelings, beliefs, and ideas are not as important as the 'material' that is there for one to teach. The job description is not to take a stand on what should be taught, but to teach what is already there. Those teachers 'technicians' are rewarded by becoming administrative personnel, who then make decisions regarding curricula. A lot of teachers who don't want to be relegated to the role of practitioner (not thinkers) leave the profession. If this control of knowledge is so predominant at this level, how can there be any substantial advances in changing the focus of how knowledge is organized in the classroom?" 
${ }^{11}$ Beyer and Zeichner (1982), op. cit., 23.

${ }^{12}$ P.H. Hirst and R.S. Peters, The Logic of Education (London: Routledge and Kegan Paul, 1970), 3.

${ }^{13}$ B.J. Johnson and J.M. Applefield, "Teaching Undergraduate Philosophy of Education: Description of a Strategy," Teaching Education, 2(1), 1988,34 and 36.

${ }^{14} \mathrm{R}$. Barrow, The Philosophy of Schooling (Brighton: Sussex: Wheatsheaf Books Ltd., 1981), 14.

${ }^{15}$ Quoted by W. Carr, "Adopting an Educational Philosophy," Cambridge Journal of Education, 16, 1986, 1-4.

${ }^{16}$ E.W. Ross and L.M. Hannay, "Toward a Critical Theory of Reflective Inquiry," Journal of Teacher Education, 37(4), 1986, 11.

${ }^{17}$ Lectures, which were kept to a minimum, were given when either the students asked for further clarification or when I felt some background to the issue(s) at hand would be helpful. The readings included selections from the writings of J. Dewey, J.R. Martin, M. Greene, H. Entwistle, W. Hare, M. Warnock, P.H. Hirst and R.S. Peters, R.F. Dearden, P.S. Wilson and J. Holt. The majority of the case studies used are available in Approaches to Teaching by G. Fenstermacher and J.F. Soltis (New York: Teachers College Press, 1986). Other case studies, based on my own teaching and my work with teachers, were also discussed. 1969), 1.

${ }^{18} \mathrm{G}$. Perry and P. Perry, Case-studies in Teaching (London: Pitman,

${ }^{19} \mathrm{An}$ analysis of the university administered course evaluations indicates that in all areas evaluated (including increased ability to think critically, the value of the readings, and fulfilling personal goals of a university career), the scores for this course are either on a par with or above the average of scores obtained by other pre-service education courses.

${ }^{20}$ The following examples of students' comments support the point made here: "This course is very useful because it addresses the context in which the other courses will take place and inspires one to think about personal teaching goals and styles." "This course opened up a whole realm of teaching issues which are most important but yet are unaddressed in the methods courses." "I can't believe that I would come to enjoy philosophy, but I must confess that I do." "The issues we discussed could be related to life in general, problems that could arise in anyone's daily life." "I found this course to be a compliment to the methods courses, this one helped me to formulate some basic ideas of the whole educational process and to put things into perspective or to question things." "Some of our other courses, though much into theory, haven't given us a view of practical applications for their theories." "In every course, I could relate an issue or idea that was dealt with in this course. I gained more from this course than from any of the others." "I found myself questioning a lot of other areas such as professors' teaching methods, their views on teaching practice, etc. This course helped me to think about all areas." "Other courses I have deal very little with issues/topics dealt with in this course. This course was much more interesting and relevant."

${ }^{21}$ W. Pinar and M.R. Grumet, "Socratic Caesura and the Theory-Practice Relationship," in Pinar (ed.), Contemporary Curriculum Discourses (Scottsdale, Arizon: Gorsuch Scarisbrick, Publs., 1988), 96. 
${ }^{22}$ Ibid., 27.

${ }^{23} \mathrm{H}$. Entwistle, "The Relationship between Educational Theory and Practice," in W. Hare and J.P. Portelli (eds.), Philosophy of Education: Introductory Readings (Calgary, Alberta: Detselig Enterprises Limited., 1988), 26.

24 Ibid., 27.

25Pinar and Grumet (1988), op. cit., 98 and 99.

${ }^{26}$ The following are some examples of the benefits of discussion and the use of case studies offered by the students: "they encourage you to think past the issue on the surface and you benefit from listening to others' opinions," "they enable us to "do' philosophy," "they give the opportunity to voice concerns and opinions and hear those of others," "they help one see something that perhaps one did not consider before," "they give one the opportunity to share ideas, criticize and relate readings with real life experience," "they prompt critical and reflective thinking," "case studies put what we were discussing into a context we could relate to," and "case studies provide insight into areas that one had not yet experienced or might not have thought would occur in the classroom."

${ }^{27}$ The observation that the issues discussed "helped one think about all areas" is made by several students. As another student put it, "Philosophy of education is evidently not limited to the philosophy of education class but permeates not only the other courses, but every course I could relate an issue or idea that was dealt with in this course. I gained more from this course than from any of the others."

${ }^{28}$ The following students' comments support the points made here: "The discussion of the issues and case studies caused me to be more critical about how to teach and many considerations about teaching, students and the classroom that I wouldn't have considered to be very important before this course." "I would go to the discussions with my opinions, however others often raised questions and issues that I failed to think about which sometimes changed or modified my prior opinions. Isn't this open-mindedness?" "Different views were expressed, and some were modified as a result of looking at and considering possible arguments for and against these views. Discussions encouraged critical thinking." "I have discovered that I will have to use a lot of my own judgement when I'm out there in the real world teaching." 